\title{
ANIMASI INFOGRAFIS BAHAYA MEROKOK MATA PELAJARAN PENJASORKES
}

\author{
Mukhammad Syahrul Kurniawan, Punaji Setyosari, Saida Ulfa
}

Jurusan Teknologi Pendidikan, Fakultas Ilmu Pendidikan, Universitas Negeri Malang Jalan Semarang 5 Malang 65145 0341-574700

msyahrulk1@gmail.com

\section{Article History}

Received: 4 September 2020, Accepted: 26 November 2020, Published: 28 Mei 2021

\begin{abstract}
Abstrak
Animasi infografis adalah bentuk visualisasi gambar dan informasi yang dimanfaatkan dalam menjelaskan materi pelajaran yang rumit disampaikan secara konvensional. Dengan animasi infografis tersebut siswa dapat dengan mudah dan mandiri memahami materi. Dengan demikian animasi infografis mempermudah siswa dalam upaya pembelajaran di rumah. Tujuan dari penelitian yaitu menghasilkan animasi infografis mata pelajaran penjasorkes materi bahaya merokok. Model penelitian yang digunakan adalah model pengembangan Lee \& Owens. Setelah melakukan review hasil pencapaian belajar animasi infografis ini memenuhi kriteria layak digunakan dalam proses pembelajaran. Bahaya Merokok dapat memberikan dampak positif dalam kegiatan pembelajaran yakni dapat menarik perhatian siswa dalam belajar dan membantu siswa dalam memahami materi.
\end{abstract}

Keyword: Infografis; Bahaya Merokok

\begin{abstract}
Infographic animation is a form of visualization of images and information that is used in explaining complicated subject matter delivered conventionally. With this animated infographic, students can easily and independently understand the material. Thus the infographic animation makes it easier for students to learn at home.The purpose of this research is to produce animated subject infographics. Penjasorkes smoking hazard material. The research model used is the Lee \& Owens development model. After reviewing the learning achievement of this infographic animation, it meets the criteria worthy of use in the learning process. The dangers of smoking can have a positive impact in learning activities, which can attract students' attention in learning and help students understand the material.
\end{abstract}

Keyword: Put 3-5 your keywords here in Bahasa Indonesia; keywords separated by semicolon 


\section{PENDAHULUAN}

Masalah rokok tidak pernah ada habisnya. Persoalan merokok menjadi permasalahan serius terutama di kota - kota besar, tidak hanya Indonesia saja, tapi bagi dunia. Di beberapa negara maju sudah banyak melakukan upaya dalam mengatasi masalah tersebut. Begitupun bagi pemerintahan dimana persoalan rokok menjadi masalah serius. Pengomsumsian rokok secara terus menerus meningkat jumlah penduduk, perilaku pola konsumsi dan gaya hidup masyarakat telah meningkatkan jumlah konsumsi rokok. Meskipun dalam 25 tahun terkhir masyarakat dan pemerhati Kesehatan dunia telah mengetahui akan resiko penyakit pembuluh darah yang dipengarui oleh kebiasaan merokok (Shah \& Cole, 2010). Ini diperlukan peranan belajar yang baik dapat mengendalikan dan menekan konsumsi rokok. Data survei sosial ekonomi nasional (susenas) tahun 2014 menyebutkan sekitar 3\% anak-anak mulai merokok sejak kurang dari 10 tahun dan persentasi jumlah orang merokok tertinggi (64\%) berada pada kelompok umur remaja (15-19 tahun). Hal ini berarti bahaya merokok pada masyarakat yang rentan yakni anakanak dan berdampak pada remaja (Depkes, 2010).Menurut Oktaviani, dkk (2018) kenyataan adanya siswa sekolah dasar yang telah merokok tentu membuat keprihatinan yang disebabkan oleh rokok yang mempunyai sifat membuat orang kecanduan, sedangkan pada usia sekolah dasar merupakan usia yang masih belia apabila anak-anak sudah kecanduan rokok maka akan lebih sulit untuk dihentikan.

Dengan perkembangan pendidikan saat ini telah menjadi faktor penting dalam berbagai aspek kehidupan, salah satunya adalah aspek pendidikan. Dalam perannya teknologi memberikan inovasi baru dalam rangka mencapai tujuan pembelajaran. Marzoan (2017) menjelaskan bahwa, beberapa kawasan di Indonesia saat ini telah menerapkan K-13 sebagai sistem pendidikannya dimana teknologi terintegrasi ke dalam mata pelajaran, artinya keterampilan teknologi harus diterapkan dan digunakan secara mutlak untuk mendukung pembelajaran. Hal itu menunjukkan dalam struktur K-13 teknologi informasi dan komunikasi hanya menjadi media pendukung didalam pembelajaran (Marzoan, 2017). Untuk meningkatkan pemahaman tentang berbahayanya konsumsi rokok, diperlukan multimedia yang lebih komunikatif dan interaktif. Salah satu jenis media yang dapat digunakan untuk pembelajaran tersebut adalah animasi. Selain itu juga animasi efektif digunakan pengembangan animasi karena terbukti bahwa penggunaan animasi sudah terbukti dapat berpengaruh dalam pembelajaran (Astuti \& Mustadi, 2014). Hal ini sejalan dalam peranan media yang juga memberikan pengaruh kongkret terhadap pengalaman siswa (Arsyad, 2002). "Media pembelajaran merupakan peranan penting dan membantu keberhasilan jalannya pendidikan di sekolah.

Menurut Mucharomah \& Wibawa (2017) proses belajar yang masih menggunakan metode ceramah dan dibantu media powerpoint dan buku teks menyebabkan pengurangan tingkat pemahaman siswa di karenakan kondisi keterbatasan ruang dan daya indra. Tujuan pembelajaran dapat tidak tercapai karena masih menerapkan media pembelajaran yang tidak sesuai. Seperti halnya siswa memiliki kendala dalam mencerna materi bahaya merokok. Dalam penerapan materi, penggunanan media perlu diperhatikan tujuan pembelajaran, sarana prasarana dan jumlah siswa tersebut (Busyaeri, Udin, \& Zaenuddin, 2016). Maka diperlukan media berupa animasi infografis guna menunjang pembelajaran. Karakteristik media animasi pembelajaran menurut Isminiati (2012), dalam sebuah media terdapat karakteristik media animasi pembelajaran yaitu terdapat rumusan pembelajaran jelas, operasional, dan terukur, terdapat materi pembelajaran yang dikemas ke dalam unit-unit atau kegiatan spesifik, tersedia contoh dan ilustrasi pendukung kejelasan pemaparan materi dan menggunakan penuturan (voice over) dengan bahasa yang sederhana untuk mudah dipahami (Luhulima, Degeng, \& Ulfa, 2017).

Dalam animasi terdapat kemampuan dalam memaparkan hal komplek atau rumit dijelaskan walau hanya menggunakan gambar dan kata - kata. Animasi dapat menjelaskan materi dengan pevisualisasikan melalui gambar. Menurut Setyosari \& Sihkabudin (2005) menjelaskan bahwa dalam media sebagai kegiatan belajar yang tidak dapat dipisahkan, dengan demikian maka pembelajaran berpengaruh dalam proses pembelajaran. Nugroho dalam (Yusuf, Amin, \& Nugrahaningsih, 2017) dalam penelitiannya menunggkapkan animasi bisa diterapkan dalam belajar dan memotivasi siswa 
dalam belajar. Menurut Mayer dan Moreno (2002) tiga fitur utama animasi yaitu gambar penganimasian sebuah gambar, gerakan - animasi dalam sebuah pergerakan, simulasi - animasi atas objek yang dibuat melalui gambar atau simulasi lain. Menurut (Sanaky, 2011) kelebihan dalam menggunakan pembelajaran berbentuk animasi yaitu: animasi bisa menyajikan objek belajar yang konkret atau pesan pembelajaran realistis, sehingga menambah pemahaman belajar siswa, dan bisa memicu siswa belajar dalam tujuan psikomotorik. Nugroho dalam (Yusuf, Amin, \& Nugrahaningsih, 2017) dalam penelitiannya mengungkapkan bahwa animasi bisa dipergunakan dalam pembelajaran sehingga memotivasi siswa belajar dan meningkatkan hasil belajar.

Infografis/infographic merupakan bentuk visualisasi gambar dan informasi. Dalam bahasa Inggris infographic merupakan penggabungan dari kata information dan graphic. Graphic sendiri memiliki arti yaitu seni visual yang melibatkan menggambar, ukiran atau huruf. Salah satu teknik yang digunakan dalam animasi yaitu infografis. Infografis merupakan salah satu cabang ilmu desain grafis, dimana dalam infografis terdapat beberapa elemen-elemen desain seperti bentuk, ukuran, tekstur, dll di dalamnya, dengan memberikan gerakan-gerakan dan terdapat informasi didalamnya. Perbedaan Infografis dengan desain grafis adalah pada media aplikasinya, apabila pada desain grafis elemenelemennya statis (diam) dan terdapat pada media cetak, sedengakan elemen pada Infografis yaitu berisikan informasi maupun gerakan gambar sehingga terlihat dinamis yang ditampilkan melalui media audio visual. Menurut Dick (2013) Inovasi yang dibawa oleh infografis adalah penggunaan komponen visual dalam penyajian informasi dan cara membangun konten (Yildirim, 2016). Menurut (Hamdani, 2011) animasi merupakan media digital elektronik yang memproses masukan agar menghasilkan suatu keluaran yang tergerak secara digital. Animasi infografis pembelajaran dipilih karena berdasarkan penelitian yang dilakukan oleh Hsin \& Cigas (2013) menyatakan bahwa animasi dapat menjadi media pembelajaran yang sangat efektif dalam pembelajaran.

Pendidikan Jasmani, Olahraga dan Kesehatanadalah suatu proses pembelajaran melalui aktivitas jasmaniyangdidesain untuk meningkatkan kebugaran jasmani, mengembangkan keterampilan motorik, pengetahuandan perilaku hidup sehatdan aktif, sikap sportif, dan kecerdasan emosi.Dalam materi bahaya merokok, model yang akan digunakanyaitu model Teaching Personal Social Responsibility (TPSR). Model ini dirancang oleh Hellison (2003) sebagai pendekatan alternatif untuk pemrograman aktivitas fisik dalam pengajaran tanggup jawab pribadi dan sosial kepada pemudaperkotaan yang seringkali berisiko karena keadaan sosial seperti kemiskinan, kekerasan, narkoba, rokok, dan masalah keluarga (Escartí, Gutiérrez, Pascual, \& Llopis, 2010). Inti dari model TPSR yaitu bahwa siswa, individu yang sukses dalam lingkungan sosial, mereka harus bertanggung jawab terhadap diri sendiri dan dengan sosial dan menggabungkan strategi dalam kontrol atas kehidupan mereka.

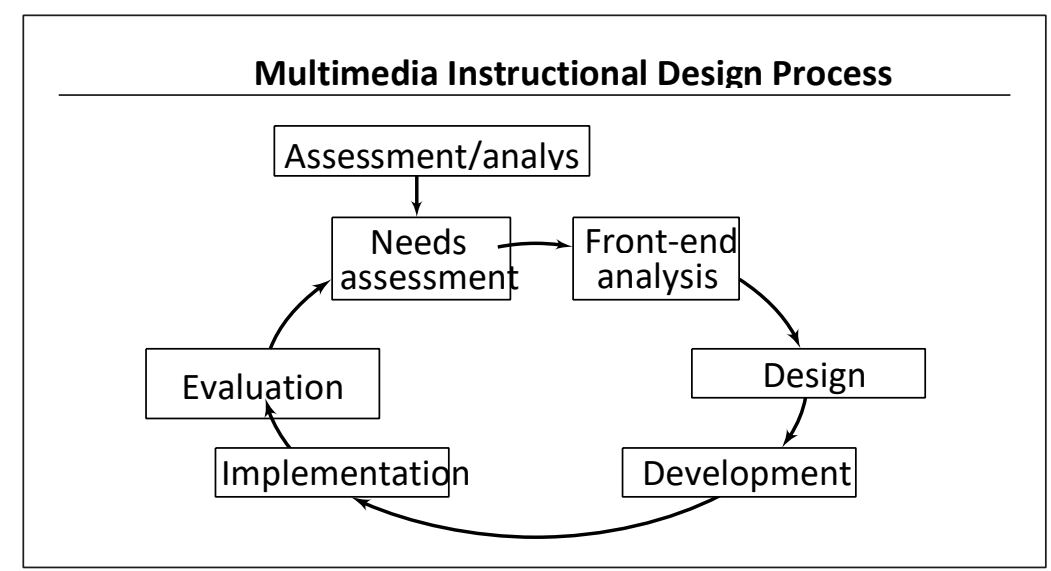

Gambar 1. Model Pengembangan Multimedia (Lee \& Owens, 2004). 


\section{METODE}

Pengembangan animasi infografis ini menggunakan model pengembangan William W. Lee \& Diana L. Owens (2004). Dalam model ini terdapat 5 tahapan yang digunakan pada pengembangan animasi infografis untuk mata pealajaran penjasorkes. Bagan model diperlihatkan pada gambar 1.

Tahapan penelitian dan pengembangan menurut William W. Lee \& Diana L. Owens terdiri dari 5 tahapan. Namun pengembangan ini hanya menggunakan sampai pada tahap tiga yaitu tahap analisis, tahap desain, dan tahap pengembangan. Tahap analisis terdiri dari analisis kebutuhan dan front-end analysis. Tahap desain terdiri dari perencanaan produk animasi infografis yang akan dikembangkan. Selanjutnya tahap pengembangan terdiri dari tahapan membuat produk animasi infografis dan review.

Subjek pada penelitian ini terdiri dari siswa kelas V SD Negeri Pekuncen Pasuruan. Dikarenakan adanya pandemic covid-19 yang melanda Indonesia, pengembangan ini hanya dapat mengambil data 10 siswa kelas V SD Negeri Pekuncen Pasuruan. Data yang dikumpulkan pada penelitian dan pengembangan ini adalah data kuantitatif dan data kualitatif. Pengembangan ini menggunakan metode observasi dan angket sebagai alat pengambilan dan pengumpulan data. Observasi dilakukan dengan cara melakukan wawancara kepada guru di SD Negeri Pekuncen Pasuruan. Pada angket instrumen ahli materi terdapat sebanyak 20 pertanyaan. Pada angket instrumen ahli materi terdapat sebanyak 16 pertanyaan. Pada angket instrumen untuk siswa terdapat sebanyak 15 pertanyaan. Instrument yang digunakan adalah angket respon atau tanggapan untuk ahli media, ahli materi dan siswa dengan kisi-kisi yang disiapkan. Angket yang digunakan menggunakan ratting scale dengan rentang nilai 4,3,2,1. Angket yang telah terisi oleh ahli dan siswa telah menunjukkan gambaran tentang kelayakan media yang dikembangkan. Tingkat kelayakan yang digunakan untuk penilaian animasi infografis berdasarkan model pengembangan ini menggunaan analisis kuantitatif deskriptif.

\section{HASIL}

Pada tahapan awal penelitian ini penilti melakukan analisis kebutuhan. Analisis kebutuhan yang dilakukan berupa observasi dan wawancara pada guru di SD Negeri Pekuncen Pasuruan. Setelah mengetahui permasalahan yang terjadi peneliti menarik kesimpulan bahwa diperlukan media pembelajaran untuk mata pelajaran penjasorkes di SD Negeri Pekuncen Pasuruan. Tahapan selanjutnya adalah tahapan desain yaitu berisi perencanaan animasi infografis yang dikembangkan. Animasi infografis dibuat menggunakan aplikasi adobe illustrator cs6, adobe after effect cs6, adobe premier pro cs6. Adobe illustrator cs6 sebagai aplikasi gambar animasi. Pada adobe after effect cs6 digunakan untuk mengatur gerakan pada animasi yang telah digambar. Selanjutnya menggunakan adobe premier pro cs6 sebagai aplikasi edit video animasi yang telah digerakkan agar menjadi animasi infografis. Tahapan terakhir adalah tahapan pengembangan, memasukkan konten berupa animasi sehingga menjadi animasi infografis pembelajaran. Selanjutnya melakukan review pada ahli media dan ahli materi. Review ahli materi dan ahli media mempunyai tujuan agar animasi infografis mendapatkan dan mengetahui kelayakan. Setelah selesai review dilakukan uji coba pada siswa. Akan tetapi hanya bisa melakukan uji coba pada 10 siswa dikarenakan pandemic covid-19 di Indonesia dan himbauan pemerintah untuk belajar dirumah.

Berdasarkan review ahli materi satu orang, ahli media satu orang, dan uji coba pada 10 siswa SD Negeri Pekuncen Pasuruan diperoleh kesimpulan bahwa animasi infografis dinyatakan layak digunakan. Hal ini dapat ditunjukkan dengan hasil data sebagai berikut. 


\section{Hasil Review Ahli Media}

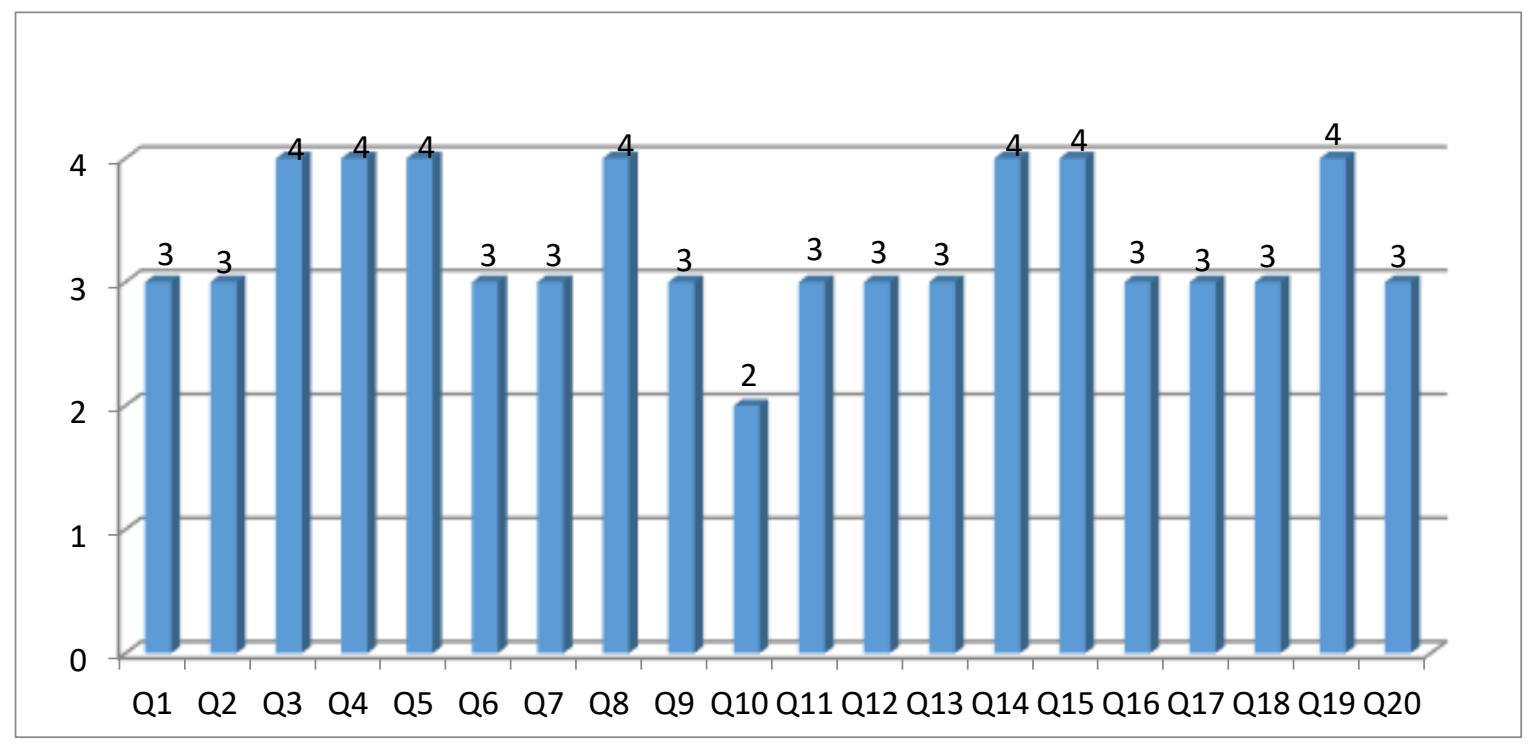

Gambar 2. Hasil skor tanggapan ahli media.

Dapat dilihat dari grafik pada Gambar 2, hasil review ahli media mendapatkan rata-rata nilai sebesar 3,3 dari rata-rata nilai yang diharapkan sebesar 4,00. Sehingga menunjukkan bahwa media animasi infografis layak digunakan dalam pembelajaran. Berdasarkan hasil kelayakan ahli media diketahui bahwa animasi infografis dinyatakan layak yaitu membangkitkan minat belajar, media membantu belajar siswa, kemenarikan warna, background, gambar, dan animasi, ketepatan pencahayaan, pemilihan jenis huruf, pemilihan warna huruf, pengaturan tata letak. Ahli media berpendapat bahwa animasi infografis sudah bagus dan dapat digunakan untuk kebutuhan penelitian. Namun beliau juga memberikan saran untuk penyempurnaan, untuk memilih audio latar yang sama, harusnya terdapat perbedaan tinggi volume antar audio latar dengan audio narrator, beberapa visual yang sederhana sebaiknya menggunakan teks saja tidak perlu gambar animasi, suara audio anak kecil sebaiknya diperbaiki sesuai karakter anak-anak, dan diharapkan memunculkan sumber rujukan pada isi konten.

\section{Hasil Review Ahli Materi}

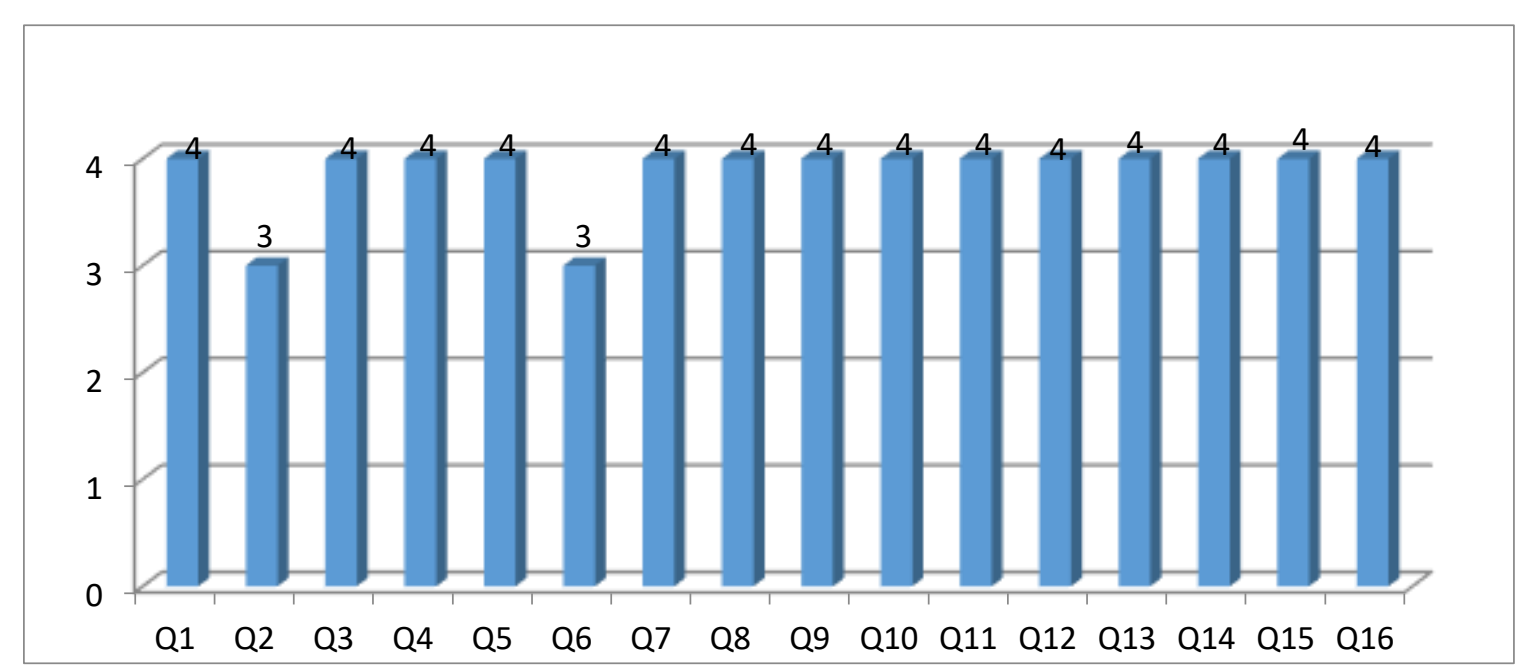

Gambar 3. Hasil skor tanggapan ahli materi.

Dapat dilihat dari grafik pada Gambar 3, hasil review ahli materi diperoleh rata-rata nilai sebesar 3,875 dari rata-rata nilai yang diharpkan sebesar 4.00. Sehingga menunjukkan bahwa media animasi 
infografis layak digunakan dalam pembelajaran. Berdasarkan hasil kelayakan ahli materi diketahui bahwa animasi infografis dinyatakan layak yaitu kesesuain dengan $\mathrm{KI}$ dan KD, relevansi materi dengan tujuan pembelajaran, kebenaran materi, kelengkapan materi, keruntutan dan kejelasan materi, kedalaman materi, kesesuaian struktur kalimat dengan EYD, keefektifan kalimat, menggunakan bahasa yang mudah di mengerti, mempermudah pendidik dalam pembelajaran, mempermudah siswa dalam pembelajaran, mempermudah peserta didik dalam memahami materi, membantu proses pembelajaran, media meningkatan pengetahuan siswa. Ahli materi berpendapat bahwa media animasi infografis sudah sesuai dan dapat diuji cobakan kepada siswa.

\section{Hasil Uji Coba Siswa}

Dapat dilihat dari grafik pada Gambar 4, hasil uji coba kepada siswa diperoleh rata-rata nilai sebesar 3,66 dari rata-rata nilai yang diharpkan sebesar 4.00. Sehingga menunjukkan bahwa media animasi infografis layak digunakan dalam pembelajaran. Berdasarkan hasil kelayakan siswa diketahui bahwa animasi infografis dinyatakan layak yaitu materi pada media animasi ini mudah dipahami, materi animasi yang disampaikan menarik perhatian, ilustrasi gambar animasi yang diberikan menarik, video

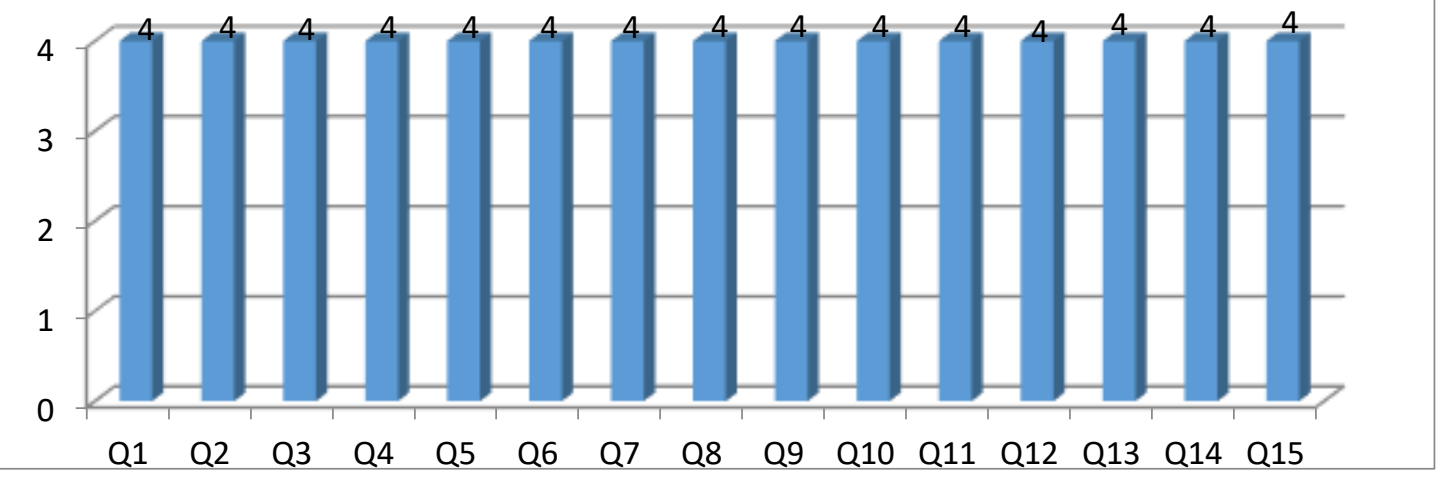

pada animasi menarik, teks pada animasi sudah jelas, kesesuaian kecepatan gerak gambar, kesesuaian suara dan musik, penggunaan jenis huruf dalam teks pada animasi ini tampak jelas, bahasa yang digunakan sesuai dengan tingkat pemahaman anda. Siswa memberikan pendapat bahwa animasi infografis sudah menarik, bagus, dan menimbulkan empati siswa bahwa merokok berbahaya. Selain itu beberapa siswa memberikan saran untuk memperjelas audio narasi pada animasi infografis.

\section{PEMBAHASAN}

Motivasi sikap tanggung jawab siswa dalam pendidikan merupakan indikator keberhasilan suatu proses pembelajaran, faktor yang mempengaruhi sikap tanggung jawab siswa terhadap pembelajaran diantaranya faktor internal dan faktor eksternal. Salah satu factor pendukung yang mempengarui sikap tanggung jawab siswa terhadap kehidupan sosial yaitu memanfaatkan atau menggunakan media pembelajaran. Menurut Handani, dkk (2016) melalui animasi juga dapat digunakan oleh guru sebagai penyampaian informasi, seperti penyuluhan, pendidikan, pembelajaran. Penggunaan media animasi infografis ini sangat membantu dalam proses pelaksanaan pembelajaran yang dimana siswa akan termotivasi akan sikap tanggung jawab mereka terhadap kehidupan sosial.

Di tengah pandemic covid -19 ini penerapan animasi infografis dapat membantu siswa dalam belajar madiri dirumah. Pandemic covid-19 merupakan wabah penyakit yang menutup akses perkembangan dunia, termasuk juga dalam perkembangan di bidang pendidikan. Menurut Purwanto, dkk (2020) Pandemi ini awalnya berakibat pada bidang ekonomi namun sekarang berimbas pada bidang pendidikan. Pemerintah memberikan keputusan untuk meniadakan pembelajaran sekolah atau tatap muka dan mengantikannya denga pembelajaran online atau daring. Namun dengan belajar dirumah memberikan dampak kepada siswa. Pada penelitian yang dilakukan Purwanto, dkk menunjukkan bahwa dengan adanya pandemi covid-19 siswa menjadi lebih jenuh dikarenakan tidak dapat bertemu dengan teman-teman mereka. Animasi infografis dapat membantu siswa menghilangkan jenuh pada 
pembelajaran online. Dengan adanya teknologi ini dapat dimanfaatkan salah satunya adalah media animasi infografis pembelajaran yang dapat membantu siswa dalam belajar dirumah. Media animasi memegang peranan yang sangat penting dalam presentasi multimedia. Siswa akan lebih tertarik dengan adanya presentasi atau aplikasi yang dapat menampilkan tayangan dalam bentuk animasi infografis (Munir, 2012).

Media animasi memberikan suatu tiruan yang jika dilakukan pada suatu peralatan yang sebenarnya terlalu mahal atau berbahaya. Animasi merupakan media audio dan visual yang tergabung dengan penceritaan cerita atau seringpula disebut dengan kartun (Fathurohman, Nurcahyo, \& Rondli, 2013). Animasi infografis ini berisikan rangkuman materi tentang bahaya merokok yang didesain sesuai dengan kehidupan disekitar kita yang disajikan menjadi sebuah media pembelajaran yang dapat digunakan oleh siswa dalam belajar mandiri dan digunakan sebagai bahan ajar oleh guru. Penyajian materi yang menggunakan perpaduan antara gambar, teks, dan audio dapat meningkatkan pemahaman siswa pada materi bahaya merokok. Animasi infografis pembelajaran ini dibuat untuk memudahkan siswa dalam belajar dan memberikan dampak empati kepada siswa, karena terdapat ilustrasi kehidupan sehari-hari. Ilustrasi visual memiliki peran yang strategis dalam pembelajaran karena merupakan bentuk komunikasi visual yang sederhana, efektif, dan efisien (Prasetyo, 2006).

Pembelajaran Penjasorkes pada materi bahaya merokok menggunakan media animasi infografis terbukti dapat meningkatkan hasil belajar siswa. Siswa lebih termotivasi dan mudah dalam memahami materi yang disajikan. Seperti halnya penilitian yang dilakukan Nugroho dalam (Yusuf, 2017) dalam penelitiannya menyatakan bahwa animasi yang digunakan pada proses pembelajaran dapat meningkatkan motivasi belajar siswa, sehingga meningkatkan hasil belajar siswa. Penelitian ini didukung oleh penelitian yang dilakukan (Harrison \& Hummell, 2010) menunjukkan bahwa media animasi sebagai media yang digunakan pada pembelajaran dapat memperkaya pengalaman dan kompetensi siswa. Dalam perkembangan teknologi saat ini media animasi infografis pembelajaran ini mampu menjelaskan konsep-konsep pembelajaran yang disertai dengan grafis, audio, dan teks, sehungga dapat menjadi sarana media yang menarik perhatian dan dapat memberi pemahaman lebih kepada siswa. Sehubungan dengan itu, pemanfaatan media animasi infografis dalam pembelajaran sangatlah membantu dalam hal meningkatkan motivasi siswa dalam belajar. Animasi infografis ini berperan sebagai bentuk saluran yang berfungsi sebagai memperjelas materi pembelajaran yang disampaikan, sehingga dapat membantu siswa untuk memahami materi yang disampaikan dan mencapai tujuan pembelajaran yang telah ditetapkan secara optimal (Sadek, HS, \& Kustandi, 2019). Selain itu, dalam temuan penelitian oleh Sakti (2013) membuktikan bahwa dalam penggunaan animasi juga dapat mempengarui dalam peningkatan pemahaman peserta didik.

Animasi infografis mempunyai kelebihan dalam memanipulasi waktu dan memanipulasi ruang, dalam hal ini animasi infografis dapat mengembangkan imajinasi peserta didik karena didalam tayangan animasi terdapat tampilan yang menarik perhatian sehingga dapat mengembangkan imajinasi peserta didik. Selain dapat digunakan untuk menarik perhatian peserta didik, dapat juga digunakan sebagai pengklarifikasi ide dan mengilustrasikan konsep sehingga peserta didik dapat memperoleh memori jangka panjang dalam materi (Cardoso, Cristiano, \& Arent, 2009). Menurut Sari \& Kosasi (2019) dalam pembuatan Infografis membutuhkan beberapa informasi dalam bentuk tulisan atau angka yang diubah menjadi bentuk lebih sederhana yaitu kombinasi gambar dan teks sehingga dapat membantu pembaca untuk cepat memahami pesan ataupun gambar itu sendiri. Sesuai pengembangan animasi infografis ini menunjukkan bahwa dengan menggunakan animasi infografis siswa lebih mudah belajar karena penyajian gambar yang diberikan mudah dipahami. Seperti halnya penyajian gambar yang persuasif pada animasi infografis untuk menjelaskan bahwa merokok itu berbahaya. Menurut penelitian yang dilakukan Khotimah, dkk (2019) penggunaan media pembelajaran terutama media yang menekankan pada pemanfaatan indera pengilihatan atau visual memberikan pengaruh terhadap perhatian siswa dalam 
belajar yang akhirnya bermuara pada capaian hasil belajar yang lebih baik. Sejalan dengan itu pengembangan animasi infografis ini juga memberikan pengaruh berupa siswa lebih berminat pada materi bahaya merokok dan terdapat peningkatan pemahaman pada siswa.

Penanaman karakter dalam pemprosesan pembelajaran dalam hal-hal kecil perlu dikerjakan dan diterapkan kepada anak sejak dini. Hal ini sesuai dengan penelitian Smithikrai, Longthong, dan Peijsel (2015) pengaruh film dapat meningkatkan kepribadian sikap mandiri dan sikap tanggung jawab. Penggunaan film berperan penting dalam peningkatan signifikan dalam pengaruh perilaku. Berdasarkan latar belakang diatas, dapat disimpulkan bahwa guru perlu menerapkan model pembelajaran Teaching Personal Social Responsibility (TPSR) dan membutuhkan animasi yang dapat diterapkan dalam mengajarkan sikap tanggung jawab dan sosial dalam meneladani nilai kehidupan sehari-hari.Model Teaching Personal Social Responsibility dan animasi dalam Pendidikan karakter materi Bahaya Merokok belum pernah diimplementasikan serta dikembangkan sehingga akan sangat berguna sebagai model dan media pembelajaran alternatif dalam proses pembelajaran. Dalam animasi infografis ini memuat unsur -unsur multimedia berupa gambar, suara, teks, dan animasi. Sehingga dengan adanya prinsip tersebut media berjalan dengan efektif. Dengan begitu animasi infografis bisa dapat dimanfaatkan dalam kegiatan belajar baik di dalam kelas atau di luarkelas.

Pengembangan animasi infografis ini dibuat berdasarkan permasalahan pada pembelajaran Penjasorkes materi bahaya merokok di SDN Pekuncen Kota Pasuruan. Pembelajaran yang dilakukan hanya menggunakan metode ceramah dan praktek sehingga kebanyakan siswa tidak tertarik dan sulit untuk memahami materi yang disajikan oleh guru, terlebih lagi materi bahaya merokok tidak dapat dipraktekkan kepada siswa. Sehingga penelitian ini memiliki tujuan untuk menghasilkan media animasi infografis pembelajaran yang valid dan layak digunakan.

Hasil dari penelitian yang dilakukan ini menggunakan ujicoba media dari 10 siswa SDN Pekuncen dengan perolehan hasil layak, dengan demikian dapat disimpulkan bahwa media animasi infografis pembelajaran yang sudah dikembangkan layak digunakan dalam pembelajaran.

\section{SIMPULAN}

Saran pemanfaatan animasi infografis bagi siswa diharapkan siswa memperhatikan penjelasan guru, siswa hendaknya menyimak tanyangan animasi infografis materi bahaya merokok untuk paham dengan materi dan termotivasi agar tidak merokok, dan siswa hendaknya menanyakan hal yang tidak dimengerti mengenai materi yang telah disampaikan. Saran pemanfaatan bagi sekolah hendaknya menggunakan animasi infografis yang menggunakan model Teaching Personal Social Responsibility (TPSR) sebagai bahan ajaruntuk pembelajaran penjasorkes. Bagi pengembang yang akan mengembangkan animasi infografis ini disarankan untuk menghasilkan animasi infografis yang lebih baik dan menarik siswa agar termotivasi dalam pembelajaran penjasorkes.

\section{DAFTAR RUJUKAN}

Arsyad, A. (2002). Media Pembelajaran (1 ed.). Jakarta: PT. Raja Gafindo Persada.

Astuti, Y. W., \& Mustadi, A. (2014). Pengaruh Penggunaan Media Film Animasi Terhadap Keterampilan Menulis Karangan Narasi Siswa Kelas V SD. Jurnal Prima Edukasia, 250-262.

Berk, R. A. (2009). Multimedia teaching with video clips: TV, movies, YouTube, and mtvU in the college classroom. International Journal of Technology in Teaching \& Learning, 5(1), 1-21.

Busyaeri, A., Udin, T., \& Zaenuddin, A. (2016). PENGARUH PENGGUNAAN VIDEO PEMBELAJARAN. Al Ibtida: Jurnal Pendidikan Guru MI, 3(1), 116-137.

Cardoso, D. C., Cristiano, P. M., \& Arent, C. O. (2009). Development of New Didactic Materials for Teaching Science and Biology: The Importance of the New Education Practices. Biological Sciences, 1-9. 
Depkes, R. (2010). Perilaku Hidup Bersih dan Sehat di Rumah Tangga. Pusat Promosi Kesehatan Departemen Kesehatan RI.

Escartí, A., Gutiérrez, M., Pascual, C., \& Llopis, R. (2010). Implementation of the Personal and Social Responsibility Model to Improve Self-Efficacy during Physical Education Classes for Primary School Children. International Journal of Psychology and Psychological Therapy, 10, 387402.

Fathurohman, I., Nurcahyo, A. D., \& Rondli, S. W. (2013). Film Animasi Sebagai Media Pembelajaran Terpadu Untuk Memacu Keaksaraan Multibahasa Pada Siswa Sekolah Dasar. Journal of Chemical Information and Modeling, 1-7.

Hamdani. (2011). Strategi Belajar Mengajar. Bandung: CV.Pustaka Setia.

Handani, S. W., Suyanto, M., \& Sofyan, A. F. (2016). Penerapan Konsep Gamifikasi Pada E-learning Untuk Pembelajaran Animasi 3 Dimensi. Jurnal Telematika, 42-53.

Harrison, H. L., \& Hummell, L. J. (2010). Incorporating Animation Concepts and Principles in STEM Education. Technology Teacher, 69(8), 20-25.

Hsin, W. J., \& Cigas, J. (2013). Short videos improve student learning in online education. Journal of Computing Sciences in Colleges, 253-259.

Khotimah, H., Supena, A., \& Hidayat, N. (2019). Meningkatkan attensi belajarsiswakelas awal melalui media visual. Jurnal Pendidikan Anak, 17-28. Diambil kembali dari https://journal.uny.ac.id/index.php/jpa

Lee, W. W., \& Owens, D. L. (2004). Multimedia Based Instructional Design. San Francisco: Pfeiffer.

Luhulima, D. A., Degeng, I. S., \& Ulfa, S. (2017). Pengembangan Video Pembelajaran Karakter Mengampuni Berbasis Animasi untuk Anak Sekolah Minggu. JINOTEP, 3, 110-120.

Marzoan. (2017). Peran Teknologi Informasi dan Komunikasi untuk Meningkatkan Kualitas Pembelajaran dalam Perspektif Kurikulum 2013. Jurnal Inovasi dan Teknologi Pembelajaran, $81-90$.

Mayer, R. E., \& Moreno, R. (2002). Animation as an Aid to Multimedia Learning. Educational Psychology Review, 87-99.

Mucharomah, R., \& Wibawa, S. C. (2017). Pengembangan Video Animasi 2D Infografis Terhadap Hasil Belajar Siswa. Jurnal IT-EDU, 104-112.

Munir. (2012). Multimedia Konsep \& Aplikasi dalam Pendidikan. Bandung: Alfabeta.

Oktaviani, N., Rusandi, N., Hendrawan, F., \& Rahayu, W. A. (2018). Perancangan Video Infografis Bahaya Merokok untuk Anak SD Menggunakan Teknik Motion Graphics. Jurnal Desain Komunikasi Visual Asia (JESKOVSIA), 1, 65-76.

Prasetyo, E. B. (2006, Oktober). PERAN ILUSTRASI VISUAL DALAM PEMBELAJARAN. Majalah Ilmiah Pembelajaran nomor 2, 2, 167-174.

Purwanto, A., Pramono, R., Asbari, M., Hyun, C. C., Wijayanti, L. M., Putri, R. S., \& Santoso, P. B. (2020). Studi Eksploratif Dampak Pandemi COVID-19 Terhadap Proses Pembelajaran Online di Sekolah Dasar. Journal EduPsyCouns, 4, 1-12.

Putri, N. (2012). Efektifitas penggunaan media video untuk meningkatkan pengenalan alat musik daerah pada pembelajaran IPS bagi anak tunagrahita ringan di SDLB 20 Kota Solok. Jurnal Ilmiah Pendidikan Khusus, 1(2), 318-328. 
Sadek, A., HS, Z., \& Kustandi, C. (2019, Februari). Pembelajaran Fotografi Dasar Melalui Video Infographic Objek Pembelajaran. Jurnal Internasional Penelitian dan Pengembangan EPRA (IJRD), 4, 56-61.

Sakti, Indra, Mega, Y., Puspitasari, Risdianto, \& Eko. (2012). Pengaruh model pembelajaran langsung (Direct Instruction) melalui media animasi berbasis macromedia flash terhadap minat belajar dan pemahaman konsep fisika siswa di SMA Plus Negeri 7 Kota Bengkulu. EXACTA, 1-10.

Sanaky, H. (2011). Media Pembelajaran: Buku Pegangan Wajib Guru Dan Dosen (Pertama ed.). Yogyakarta: Kaukaba.

Sari, Y. W., \& Kokasih, E. (2019). Pemanfaatan Infografis Animasi Dalam Pembelajaran Menulis Teks Ekslanasi. Seminar Internasional Riksa Bahasa XIII, 949-956.

Setyosari, P., \& Sihkabuden. (2005). Media Pembelajaran. Elang Mas.

Shah, R. S., \& Cole, J. W. (2010). Smoking and stroke: The more you smoke the more you stroke. Expert Review of Cardiovascular Therapy. Diambil kembali dari https://doi.org/10.1586/erc.10.56

Smithikrai, C., Longthong, N., \& Peijsel, C. (2015). Effect of Using Movies to Enhance Personal Responsibility of University Students. Published by Canadian Center of Science and Education, 11(5), 1-9. doi:10.5539/ass.v11n5p1

Yildirim, S. (2016, July). Infographics for Educational Purposes: Their Structure, Properties and Reader Approaches. TOJET: The Turkish Online Journal of Educational Technology, 15(3), 98-110.

Yusuf, M. M., Amin, M., \& Nugrahaningsih. (2017). Developing of instructional media-based animation video on enzyme and metabolism material in senior high school. Jurnal Pendidikan Biologi Indonesia, 3(3), 254-257. 